\title{
Successful Treatment of Recurrent Pilonidal Sinus with Laser Epilation
}

\author{
Nerea landa, MD, Oscar Aller, mD, Nagore landa-Gundin, RN, Jaione Torrontegui, RN, and \\ Jose L. AZPIAZU, MD
}

Dermitek Clinic of Laser, Dermatology and Aesthetic Surgery, Bilbao, Basque Country, Spain

BACKGROUND. Pilonidal disease is a chronic disease of the natal cleft. Recurrent follicular infection is the causative factor. Surgical treatment has a significant failure rate, and recurrence is common. Laser removal of hair in the natal cleft could be an alternative to surgery.

OBJECTIVE. To determine the effectiveness of laser hair removal in the natal cleft on pilonidal disease.

METHODS. Six young men with recurrent pilonidal disease were treated with laser epilation in our clinic from 2000 to 2003. Most patients had a history of one or more surgical treatments in the area, and all patients had suffered recurrent folliculitis for years. An alexandrite laser was mostly used, although, occasionally, an intense pulsed light device was used. The number of epilation treatments ranged from 3 to 11, performed at 6- to 8-week intervals.

RESULTS. All patients experienced progressive resolution of the folliculitis with the laser epilation treatments. No more surgical treatments have been needed. The treatments were simple and quick, and there were no complications.

CONCLUSION. Laser epilation of the natal cleft should be considered a first choice treatment for recurrent pilonidal disease. Preventive laser epilation of the natal cleft in patients with recurrent folliculitis could avoid future surgery.

NEREA LANDA, MD, OSCAR ALLER, MD, NAGORE LANDA-GUNDIN, RN, JAIONE TORRONTEGUI, RN, AND JOSE L. AZPIAZU, MD, HAVE INDICATED NO SIGNIFICANT INTEREST WITH COMMERCIAL SUPPORTERS.

PILONIDAL DISEASE is a problem suffered mostly by young men with symptoms of recurrent infection of the area of the buttock crease that often evolves to a chronic fistula that is unresponsive to antibiotics. In these cases, surgery with excision of the infected tissue has been the approach to treatment. ${ }^{1}$ Different modalities of surgery have been used, but they often result in recurrence, and additional surgery is needed. Although the ultimate cause is not clear, it is known that the hair follicles are involved with recurrent bacterial infection. New methods of laser hair removal with different light sources permanently destroy the hair follicles of a certain area by transmitting enough heat to the target hair. Progressive hair destruction is achieved with an increasing number of laser treatments, resulting in hair reduction for years of follow-up. Eliminating the hair of the affected area could be a new approach to the treatment of patients with pilonidal disease.

Address correspondence and reprint requests to: Nerea Landa, MD, General Concha, 12-1, Bilbao, Bizkaia 48008, Basque Country, Spain, or e-mail: dermitek@dermitek.com.

\section{Patients and Methods}

Between 2001 and 2003, six young men aged 16 to 29 years came to our clinic with a history of recurrent pilonidal sinus disease in the natal cleft. Five of the patients had undergone surgical treatment before admission. All of them had a history of recurrent episodes of chronic bacterial folliculitis of the hair in the buttock crease area and sometimes in other distant areas, such as the buttocks or back, which required topical and oral antibiotics.

Prior to the study, two patients had surgery once, two patients had surgery twice, and one patient had surgery three times owing to recurrence after the first surgery. They all had thick hair in the natal cleft. Patients were treated with laser epilation using an alexandrite laser (GentleLase, Candela, Wayland, MA, USA) with a spot size of $18 \mathrm{~mm}$ using the following parameters: fluence 16 to $18 \mathrm{~J} / \mathrm{cm}^{2}$, pulse duration 3 milliseconds, and cooling spray 40 to 60 milliseconds with a 40 - to 60 -millisecond delay. In two patients, a few treatments were also performed with an intense pulsed light device (Epilight, Lumenis, Santa Clara, CA, USA) with 695 to $755 \mathrm{~nm}$ filters and the following parameters: 30 to $37 \mathrm{~J} / \mathrm{cm}^{2}, 2$ to 5 milliseconds, and a 30- to 50-millisecond delay. Hair was removed in a round area 4 to $5 \mathrm{~cm}$ around the problem- 
atic sinus. Treatments were performed at 6- to 8-week intervals for the first three to four treatments and then every 8 to 16 weeks until remission of infection and removal of most of the hair. Two subjects had a family history of pilonidal sinus.

This study involves case studies and is not a placebocontrolled randomized study.

\section{Results}

Progressive hair loss in the natal cleft was achieved (Figures 1 and 2) in all patients.

Simultaneously, infectious folliculitis progressively decreased in number and intensity. To date, most patients have not experienced more infections in the epilated area. At the time this article was written, all patients had experienced partial or complete remission of the follicular infection in the treated area. One patient had a relapse of folliculitis after two treatments that resolved with antibiotics and is presently well, with ongoing treatments. None of the patients have required further surgical treatment to date. No side effects were reported. The degree of satisfaction of the patients is very high. Table 1 summarizes the results.

\section{Discussion}

Pilonidal sinus is a chronic recurrent infectious disease in the region of the buttock crease. The condition results from a reaction to hairs embedded in the skin, commonly occurring in the cleft between the buttocks. The disease is more common in men and frequently occurs between puberty and age 40 . It is also common in obese people and
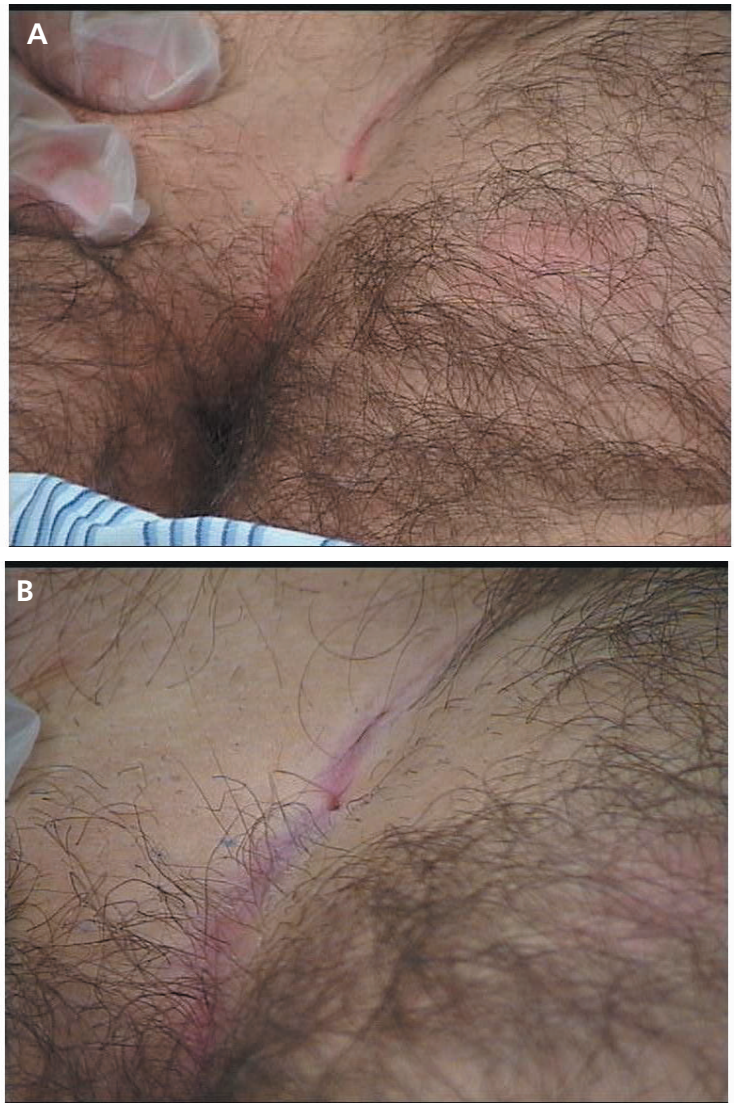

Figure 1. (A and B) Patient 3: two views of the natal cleft after four laser treatments.

in those with thick, stiff body hair. Symptoms vary from a small dimple to a large painful abscess. Often the area will drain pus. The infection may cause fever. After the abscess

Table 1. Results of Laser Epilation Treatments in Pilonidal Disease

\begin{tabular}{|c|c|c|c|c|c|c|c|c|c|c|}
\hline Patient & Age & $\begin{array}{l}\text { Family } \\
\text { History }\end{array}$ & $\begin{array}{c}\text { Past } \\
\text { History }\end{array}$ & $\begin{array}{c}\text { Past } \\
\text { Surgical } \\
\text { Treatments }\end{array}$ & $\begin{array}{c}\text { Number } \\
\text { of } \\
\text { Treatments }\end{array}$ & $\begin{array}{c}\text { First } \\
\text { Epilation } \\
\text { Date }\end{array}$ & Device & Parameters & $\begin{array}{l}\text { Follow-up } \\
\text { after Last } \\
\text { Treatment } \\
\quad \text { (mo) }\end{array}$ & $\begin{array}{c}\text { Actual Status } \\
\text { March } 2004\end{array}$ \\
\hline 1 & 23 & No & $\begin{array}{l}\text { Chronic } \\
\text { folliculitis }\end{array}$ & 1 & 7 & $04 / 2001$ & $\begin{array}{c}\text { IPL } \\
\text { alexandrite }\end{array}$ & $\begin{array}{c}33-37 / 2 / 5.5 / 30 \\
16 \mathrm{~J} / 50-50\end{array}$ & 10 & $\begin{array}{l}\text { No } \\
\text { recurrence }\end{array}$ \\
\hline 2 & 26 & No & $\begin{array}{l}\text { Chronic } \\
\text { folliculitis }\end{array}$ & 2 & 11 & $05 / 2001$ & $\begin{array}{c}\text { IPL } \\
\text { alexandrite }\end{array}$ & $\begin{array}{c}30-37 \mathrm{~J} / 5.5 / 30-50 \\
14-18 \mathrm{~J} / 40-20\end{array}$ & 11 & $\begin{array}{l}\text { No } \\
\text { recurrence }\end{array}$ \\
\hline 3 & 19 & Yes & $\begin{array}{l}\text { Chronic } \\
\text { folliculitis }\end{array}$ & 0 & 7 & $05 / 2002$ & Alexandrite & $16-18 \mathrm{~J} / 40-40$ & 7 & $\begin{array}{l}\text { No } \\
\text { recurrence }\end{array}$ \\
\hline 4 & 21 & No & $\begin{array}{l}\text { Chronic } \\
\text { folliculitis }\end{array}$ & 3 & 6 & $05 / 2002$ & Alexandrite & $18 \mathrm{~J} / 40-40$ & 6 & $\begin{array}{l}\text { No } \\
\text { recurrence }\end{array}$ \\
\hline 5 & 24 & No & $\begin{array}{l}\text { Chronic } \\
\text { folliculitis }\end{array}$ & 2 & 4 & $01 / 2003$ & Alexandrite & $16-18 \mathrm{~J} / 50-50$ & 6 & $\begin{array}{l}\text { No } \\
\text { recurrence }\end{array}$ \\
\hline 6 & 29 & Yes & $\begin{array}{l}\text { Chronic } \\
\text { folliculitis }\end{array}$ & 1 & 3 & $05 / 2003$ & Alexandrite & $16 / 50-50$ & 6 & $\begin{array}{c}\text { Recurrence } \\
11 / 2003 \\
\text { resolved } \\
\text { with } \\
\text { antibiotics }\end{array}$ \\
\hline
\end{tabular}

IPL = intense pulsed light. 


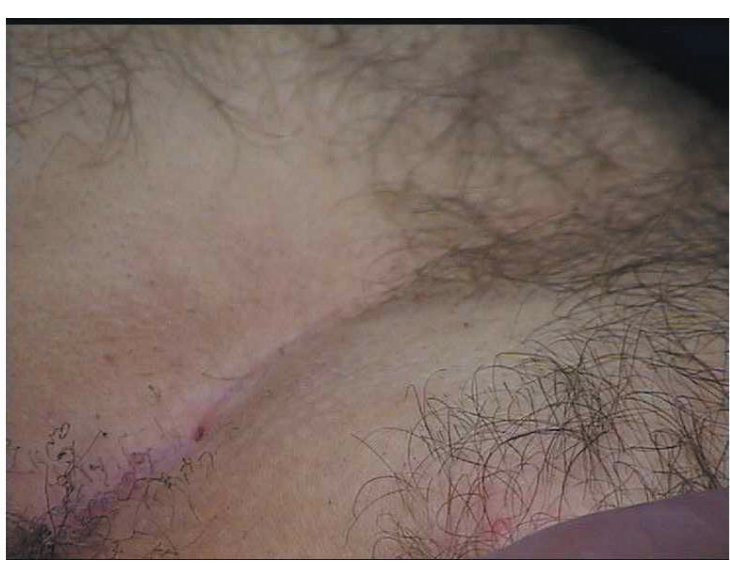

Figure 2. Patient 3: the natal cleft after seven treatments.

resolves, either by itself or with antibiotics, many patients develop a pilonidal sinus. The sinus is a cavity below the skin that connects to the surface with one or more small opening tracts. Patients develop recurrent infections and inflammation of the sinus tracts. The chronic disease causes episodes of swelling, pain, and drainage. ${ }^{1,2}$ Surgery is almost always required to resolve this condition. Different surgical techniques vary from unroofing the sinuses to excision and closure with flaps and skin grafts..$^{3-8}$ Larger operations require longer healing times, sometimes several weeks. Surgery has a significant failure rate, with a high incidence of recurrence following the procedure. ${ }^{9,10}$ The cause of this disease has not been totally clarified, but deep infection of the hair follicles in the area is a common factor and the triggering factor of the disease. Permanent hair removal with the new laser and light-based devices would eliminate the hair and, consequently, the possibility of infection. To our knowledge, three articles have been published about treatment of pilonidal sinus with laser epilation. ${ }^{11-13}$ One is a case report of a patient who was satisfactorily treated with a ruby laser after 6 months of follow-up. ${ }^{11}$ Another is a study of 14 patients treated over 5 years with an alexandrite laser. Of the 14 patients, 4 had ongoing disease and received further epilation. After this, all patients were healed, with no reported complications. We considered laser hair removal an aid to surgery but only temporarily because recurrences may still occur. ${ }^{12}$ Our contention is that the more hair the patient has in the area, the more treatments are needed to remove the maximum number of hairs and, consequently, to prevent recurrences. For this reason, it is possible that ongoing cases would achieve remission with more laser treatments.

Laser hair removal has been reported to be effective in chronic follicular disorders in other skin areas, such as the groin and beard. ${ }^{14-16}$ We presented a study in 1999 of 25 women with folliculitis in the groin, legs, axilla, and buttocks that was treated by laser epilation. The women in our series with recurrent abscesses in the groin and axilla who had had previous several surgical drainages did not need more surgery after laser epilation. Moreover, all of the women with recurrent folliculitis have been in remission since treatment. ${ }^{17}$ In our cases, the treatment was safe, rapid, and easy to tolerate. All of our patients experienced improvement from the first few treatments and are very satisfied with the results. Although more follow-up is needed to be sure of the definitive results and to exclude recurrences, to date, none of the previous treatments, such as antibiotics or surgery, have been as satisfactory as laser hair removal. It is interesting to remark that one of our patients has done the treatment to prevent recurrent infection, although he had not had previous surgery. The episodes of folliculitis stopped in this patient. We conclude that laser hair removal of the natal cleft could be the first choice of treatment in patients with pilonidal sinus disease. Moreover, in patients with recurrent folliculitis, natal cleft laser hair removal resolves the folliculitis and could prevent future surgery.

\section{References}

1. Hull TL, Wu J. Pilonidal disease. Surg Clin North Am 2002;82:1169-85.

2. Chintapatla S, Safarani N, Kumar S, Habooubi N. Sacrococcygeal pilonidal sinus: historical review, pathological insight and surgical options. Techn Coloproctol 2003;7(1):3-8.

3. Hegele A, Strombach FJ, Schonbach F. Reconstructive surgical therapy of infected pilonidal sinus. Chirurg 2003;74:749-52.

4. Theodoropoulos GE, Vlahos K, Lazaris AC, et al. Modified Bascom's asymmetric midgluteal cleft closure technique for recurrent pilonidal disease: early experience in a military hospital. Dis Colon Rectum 2003;46:1286-91.

5. Garrido A, Ali R, Ramakrishnan V, et al. Reconstruction of the natal cleft with a perforator-based flap. Br J Plast Surg 2002;55:671-4.

6. Oncel M, Kurt N, Kement M, et al. Excision and marsupialization versus sinus excision for the treatment of limited chronic pilonidal disease: a prospective, randomized trial. Techn Coloproctol 2002;6:165-9.

7. Thomas D. Comparison of three methods in surgical treatment of pilonidal disease. Aust N Z J Surg 2002;72:561-4.

8. Gupta PJ. Pilonidal sinotomy with radiofrequency. J Coll Physicians Surg Pak 2003;13:540-1.

9. Bascom J, Bascom B. Failed pilonidal surgery: new paradigm and new operation leading to cures. Arch Surg 2002;137:1146-50; discussion 1151.

10. Iesalnieks I, Furst A, Rentsch M, Jauch KW. Primary midline closure after excision of a pilonidal sinus is associated with a high recurrence rate. Chirurg 2003;74:461-8.

11. Lavelle M, Jafri Z, Town G. Recurrent pilonidal sinus treated with epilation using a ruby laser. J Cosmet Laser Ther 2002;4:45-7.

12. Odili J, Gault D. Laser depilation of the natal cleft-an aid to healing the pilonidal sinus. Ann R Coll Surg Engl 2002;84:29-32.

13. Dows AM, Palmer J. Laser hair removal for recurrent pilonidal sinus disease. J Cosmet Laser Ther 2002;4:91.

14. Kauvar AN. Treatment of pseudofolliculitis with a pulsed infrared laser. Arch Dermatol 2000;136:1343-6.

15. García-Zuazaga J. Pseudofolliculitis barbae: review and update on new treatment modalities. Mil Med 2003;168.561-4.

16. Scheinfeld NS. A case of dissecting cellulitis and review of the literature. Dermatol Online 2003,9(1):8.

17. Torrontegui J, Landa N. Chronic follicular disorders treated with intense pulse light epilation. International Meeting of the European Society for Laser Aesthetic Surgery; 2000 Mar 24-26; Tarragona, Spain. Cambrills (Tarragona), Spain: ESLAS 2000 Congress Secretariat, Tarragona, Spain. 